\title{
Role of Serum Interleukin-10 as a Marker of T-helper 2 Activity in Egyptian Chronic Hepatitis C Patients
}

\author{
Yousri M. $\mathrm{H}^{1}$; Mohamed E. F. ${ }^{2}$; Amal F. $G^{1}$.; \\ Mohamed H. Mohamed Ali ${ }^{1}$ and Haidy E. A. ${ }^{1}$ \\ Medical Biochemistry ${ }^{1}$ and Tropical Medicine ${ }^{2}$ Depts. \\ Faculty of Medicine - Zagazig University
}

\begin{abstract}
The present study included 45 subjects classified into three groups: Group I (control group) which comprised 15 healthy individuals, group II which comprised 15 patients with positive ELISA test for hepatitis C, but negative PCR test for HCV RNA and Group III which included 15 patients with positive ELISA test for hepatitis C and positive PCR test for HCV RNA. As regards IL-10 level the present study showed that there was highly significant increase in the level of IL - 10 in group II and III when compared with control group $(p<0.001)$ as positive ELISA test for hepatitis $C$ and positive PCR test for HCV RNA was an indication to the activity of HCV. It just indicated that the patient was carrier of HCV infection. The study revealed a positive significant correlation between IL 10 and ALT, AST, GGT and ALP. In conclusion, from the present study, it could be concluded that IL -10 as a marker of T-helper 2 activity increases with chronic hepatitis $C$ and that increase is related to the increased chronicity of the disease so it may be a useful marker in diagnosis of hepatitis $C$ patients.
\end{abstract}

\section{INTRODUCTION}

Interleukin 10 is considered as a typical cytokine released from activated T- helper type 2 cells. A complete-IL-10 molecule includes 160 amino- acids with molecular weight ranging from 35 to $70 \mathrm{KDA}$, and can suppress proliferation and cytokine secretion of T- helper type I cells such as IL-2, IFN- $\gamma$. It can, also, suppress immuno - reaction induced by $\mathrm{T}$ - helper -1 - cells and induce Blymphocytes into presenting antigen that matches with the molecule of major histocompitability complex II (MHC II) to facilitate humoral immunity and neutralize extracellular pathogenesis ${ }^{(\mathbf{1})}$.
Recruitment of virus-specific Tlymphocyte subpopulation to liver sites: chronic HCV infection implies a key role for the immune response in host virus interaction. In spite of a multi-specific and polyclone cytotoxic function exerted by $\mathrm{CD} 8+$ lymphocytes, CD-mediated activity weak. This allows the infection to persist which is responsible for development of chronic hepatitis $\mathrm{C}$ (CH-C) such a finding outline the occurrence of a possible relationship between cytokine $(\mathrm{CK})$ production by CD4 subsets, i.e. $\mathrm{T}$ helper (Th 1) or Th2 cells, and the clinical outcome ${ }^{(2)}$.

A prevalence of Th 1 derived CK occurs in infected liver, while increased amounts of Th 2 related CK 
are usually found in peripheral blood. Peripheral blood mononuclear cells cultures from $\mathrm{CH}-\mathrm{C}$ subjects exhibits an impaired IFN- $\gamma$ production and favor IL-10 induced effects ${ }^{(2)}$.

Type I and type II lymphocytes are not derived from different lineages but develop from the same precursors, and their differentiation is influenced by the environment during priming. The most important signals are cytokines themselves: IL-12 produced by activated macrophages is the principle cytokine inducing type I responses, whereas the development of type 2 lymphocytes is induced by IL-4 and IL-10 ${ }^{(3)}$.

The cytokine interleukin-10 (IL10) has pleiotropic effects on a number of different cell types. In general it is regarded as a suppressor of immune responses because it inhibits the secretion of proinflammatory and antiviral cytokines such as TNF- $\alpha$ and interferon- $\gamma$ (IFN$\gamma)$. IL-10 inhibits the development and activation of CD4+ T-helper lymphocytes with a Th1 (IFN- $\gamma$ secreting) phenotype ${ }^{(4)}$.

Interleukin-10-secreting antigenspecific regulatory cells may contribute to viral persistence, and demonstrate the peripheral blood mononuclear cells (PBMC), from chronically $\mathrm{HCV}$ - infected patients secrete IL-10, but not IFN- $\gamma$ in response to $\mathrm{HCV}$ non-structural protein (NS4) ${ }^{(5)}$.

A neutralizing anti-IL-10 antibody restored this defective antigen- specific IFN- $\gamma$ production in vitro. PBMC from normal individuals secreted IL-10 in response to NS4 suggesting that cells of innate immune system in addition to T-cells produced IL-10 in the HCV infected patients ${ }^{(5)}$.

On basis of the previous data the present work was designed to evaluate the role of Interleukin 10 as a marker of $\mathrm{T}$ - helper 2 activity and its importance in chronicity of hepatitis $\mathrm{C}$ virus.

\section{SUBJECTS \& METHODS}

Forty five subjects were included in the study. They were divided into 3 groups: Group (I) (control group). This group comprised 15 normal apparently healthy volunteers. Group (II): This group comprised 15 patients with positive ELISA test for hepatitis $\mathrm{C}$ but negative PCR test for $\mathrm{HCV}$ RNA. All were free from any disease that interfere with the parameters to be investigated in the present study. Group (III): This group included 15 patients with positive ELISA test for hepatitis $\mathrm{C}$ and positive PCR test for HCV RNA. All were free from any disease that interferes with the parameters to be investigated in the present study except hepatitis C.

Fasting morning venous blood samples $(5 \mathrm{ml})$ were withdrawn from all subjects for determination of: interleukin 10 by ELISA, ALT, AST, ALP, GGT enzymes by spectro photometric methods, Anti HCV antibodies by ELISA ( $2^{\text {nd }}$ generation), HCV RNA detections by RT-PCR technique, serum albumin, total proteins, $\mathrm{A} / \mathrm{G}$ ratio, prothrombin concentration and INR.

One-way Analysis of Variance (ANOVA) was used to compare between means. Duncan's post-hoc test was used for pair-wise comparison between the means when 
ANOVA test is significant. The significance level was set at $\mathrm{P} \leq 0.05$. Statistical analysis was performed with SPSS 15.0® (Statistical Package for Scientific Studies) for Windows.

All data were expressed as mean \pm SD for quantitative variables; number and percentage for qualitative ones ${ }^{(6)}$.

\section{RESULTS}

The results of the current study revealed that:

- The comparison between liver function tests (ALT, AST, ALP, GGT, serum albumin, total protein, albumin/globulin ratio, prothrombin concentration and IL10) in the three studied groups are shown in table (1) and figures I, II, III, IV and V.

- There was highly significant increase of ALT in group II and III when compared with control group $(\mathrm{P}<0.001)$, also there was highly significant increase of ALT in group III when compared with group II $(\mathrm{P}<0.001)$ (table 1$)$.

- There was highly significant increase of AST in group II and III when compared with control group $(\mathrm{P}<0.001)$, also there was highly significant increase of AST in group III when compared with group II $(\mathrm{P}<0.001)$ (table 1).

- There was highly significant increase of ALP in group II and III when compared with control group $(p<0.001)$, also there was highly significant increase of ALP in group

${ }^{\circledR}$ SPSS, Inc., Chicago, IL, USA.
III when compared with group II $(\mathrm{P}<0.001)($ table 1).

- There was highly significant increase of GGT in group II and III when compared with control group $(\mathrm{P}<0.001)$, also there was highly significant increase of GGT in group III when compared with group II $(\mathrm{p}<0.001)($ table 1$)$.

- There was highly significant decrease of serum albumin in group II when compared to control group $(\mathrm{P}<0.001)$. There was no statistically significant difference between group III and the control group $(\mathrm{P}>0.05)$. The mean serum albumin of group III was statistically significantly higher than group II ( $\mathrm{P}<0.001)$.

- There was highly significant decrease of total protein in groups II and III when compared with the control group $(\mathrm{P}<0.001)$. There was no statistically significant difference between group II and group III $(\mathrm{P}>0.05)$.

- There was statistically significant increase of $\mathrm{A} / \mathrm{G}$ in group III when compared with the control group ( $\mathrm{P}$ $=0.01)$. There was no statistically significant difference between group II and control group $(\mathrm{P}>$ $0.05)$.

- There was highly significant decrease of prothrombin concentration in groups II and III when compared with the control group $(\mathrm{P}<0.001)$. There was a statistically significant increase in prothrombin concentration in group III when compared with group II (P $<0.001)$.

- There was highly significant increase of IL-10 in groups II and III when compared with control 
group $(\mathrm{P}<0.001)$, also there was highly significant increase of IL-10 in group III when compared with group II $(\mathrm{P}<0.001)$ (table 1$)$. There was, also, positive correlation which was significant between
ALT, AST, ALP, GGT, Serum albumin, Total protein, albumin/globulin ratio, and prothrombin concentration and IL10. (table 2).

Table (1): Comparison between the three studied groups as regards liver function tests and IL-10

\begin{tabular}{|c|c|c|c|c|c|}
\hline & $\begin{array}{c}\text { Group I } \\
(\mathrm{N}=15)\end{array}$ & $\begin{array}{c}\text { Group II } \\
(\mathbf{N}=15)\end{array}$ & $\begin{array}{c}\text { Group III } \\
(\mathbf{N}=15)\end{array}$ & $\mathbf{F}$ & $\mathbf{P}$ \\
\hline $\begin{array}{c}\text { ALT }(\mathrm{IU} / \mathrm{L}) \\
\text { Mean } \\
\pm \mathrm{SD} \\
\mathrm{p}_{1} \\
\mathrm{p}_{2}\end{array}$ & $\begin{array}{l}19.4 \\
4.137\end{array}$ & $\begin{array}{r}44.13 \\
2.722 \\
<0.001 *\end{array}$ & $\begin{array}{c}52.73 \\
2.12 \\
<0.001 * \\
<0.001 *\end{array}$ & $464.387^{*}$ & $\begin{array}{c}0.00 \\
\mathrm{~S}\end{array}$ \\
\hline $\begin{array}{c}\text { AST }(\mathrm{IU} / \mathrm{L}) \\
\text { Mean } \\
\pm \mathrm{SD} \\
\mathrm{p}_{1} \\
\mathrm{p}_{2}\end{array}$ & $\begin{array}{l}19.13 \\
3.54\end{array}$ & $\begin{array}{r}45.47 \\
2.066 \\
<0.001 *\end{array}$ & $\begin{array}{rl} & 54.47 \\
2.066 & 060 \\
< & 0.001 * \\
< & 0.001 *\end{array}$ & $719.523 *$ & $\stackrel{0.00}{\mathrm{~S}}$ \\
\hline $\begin{array}{c}\text { ALP (IU/L) } \\
\text { Mean } \\
\pm \mathrm{SD} \\
\mathrm{p}_{1} \\
\mathrm{p}_{2}\end{array}$ & $\begin{array}{l}122.2 \\
21.69\end{array}$ & $\begin{array}{c}328.67 \\
8.17 \\
<0.001 *\end{array}$ & $\begin{array}{c}361.53 \\
6.45 \\
<0.001 * \\
<0.001 *\end{array}$ & 1308.559 & $\stackrel{0.00}{\mathrm{~S}}$ \\
\hline $\begin{array}{c}\text { GGT }(\mathrm{IU} / \mathrm{L}) \\
\text { Mean } \\
\pm \mathrm{SD} \\
\mathrm{p}_{1} \\
\mathrm{p}_{2}\end{array}$ & $\begin{array}{l}26.67 \\
8.07\end{array}$ & $\begin{array}{c}68.87 \\
1.51 \\
<0.001 *\end{array}$ & $\begin{aligned} & 77.67 \\
& 2.55 \\
< & 0.001 * \\
< & 0.001 *\end{aligned}$ & $452.653 *$ & $\begin{array}{l}0.00 \\
\mathrm{~S}\end{array}$ \\
\hline $\begin{array}{c}\text { Albumin }(\mathrm{g} / \mathrm{dl}) \\
\text { Mean } \\
\pm \mathrm{SD} \\
\mathrm{p}_{1} \\
\mathrm{p}_{2} \\
\end{array}$ & $\begin{array}{c}4.05 \\
0.3\end{array}$ & $\begin{array}{c}3.31 \\
0.1 \\
<0.001 *\end{array}$ & $\begin{array}{l}3.87 \\
0.2 \\
>0.05 \\
<0.001 * \\
\end{array}$ & $40.029 *$ & $\stackrel{0.00}{\mathrm{~S}}$ \\
\hline $\begin{array}{c}\text { T. protein }(\mathrm{g} / \mathrm{dl}) \\
\text { Mean } \\
\pm \mathrm{SD} \\
\mathrm{p}_{1} \\
\mathrm{p}_{2} \\
\end{array}$ & $\begin{array}{l}6.93 \\
1.1\end{array}$ & $\begin{array}{c}5.67 \\
0.2 \\
<0.001 *\end{array}$ & $\begin{array}{c}5.86 \\
0.3 \\
<0.001 * \\
>0.05\end{array}$ & $14.880^{*}$ & $\begin{array}{l}0.00 \\
\mathrm{~S}\end{array}$ \\
\hline $\begin{array}{c}\mathrm{A} / \mathrm{G} \\
\mathrm{Mean} \\
\pm \mathrm{SD} \\
\mathrm{p}_{1} \\
\mathrm{p}_{2}\end{array}$ & $\begin{array}{l}1.53 \\
0.4\end{array}$ & $\begin{array}{c}1.41 \\
0.3 \\
0.721\end{array}$ & $\begin{array}{c}1.98 \\
0.4 \\
0.01 * \\
0.001 *\end{array}$ & $8.366^{*}$ & $\begin{array}{c}0.001 \\
\mathrm{~S}\end{array}$ \\
\hline $\begin{array}{c}\text { Prothrombin } \\
\text { conc. } \% \\
\text { Mean } \\
\pm \mathrm{SD} \\
\mathrm{p}_{1} \\
\mathrm{p}_{2}\end{array}$ & $\begin{array}{l}84.2 \\
7.2\end{array}$ & $\begin{array}{c}47.2 \\
6.1 \\
<0.001 *\end{array}$ & $\begin{array}{c}62.73 \\
4.2 \\
<0.001 * \\
<0.001 *\end{array}$ & $143.662 *$ & $\stackrel{0.00}{\mathrm{~S}}$ \\
\hline $\begin{array}{c}\text { IL-10 (ng/dl) } \\
\text { Mean } \\
\pm \mathrm{SD} \\
\mathrm{p}_{1} \\
\mathrm{p}_{2} \\
\end{array}$ & $\begin{array}{l}1.87 \\
0.89\end{array}$ & $\begin{array}{c}4.31 \\
1.199 \\
<0.001 *\end{array}$ & $\begin{aligned} & 6.22 \\
& 1.46 \\
&< 0.001 * \\
&< 0.001 * \\
&\end{aligned}$ & $48.997^{*}$ & $\begin{array}{l}0.000 \\
\mathrm{~S}\end{array}$ \\
\hline
\end{tabular}

$\mathrm{P}_{1}$ : Compared to Group I (Control group)

$\mathrm{P}_{2}$ : Compared to Group II 


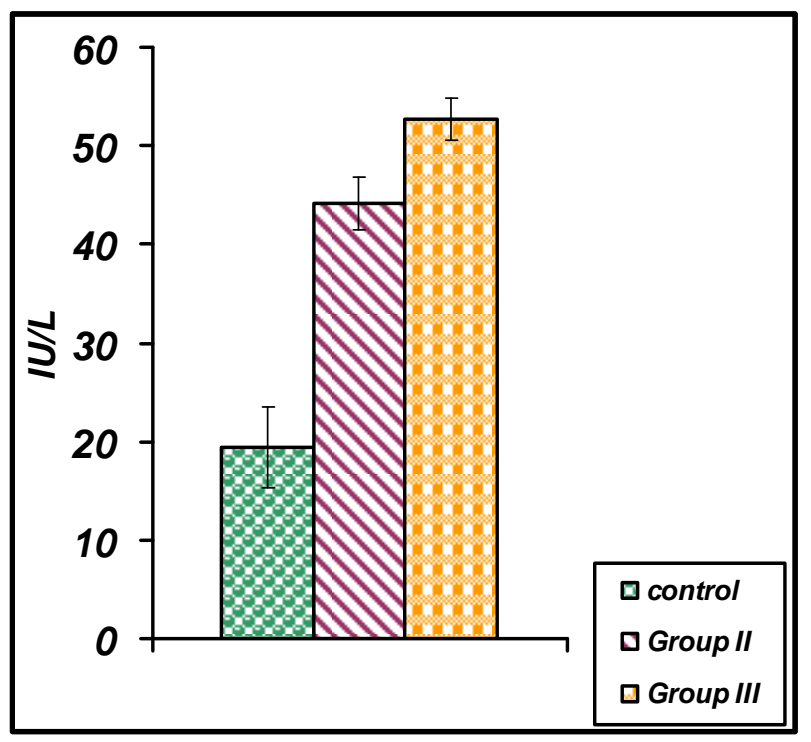

Fig (1): Mean \pm SD of ALT level (IU/L) in the three studied groups

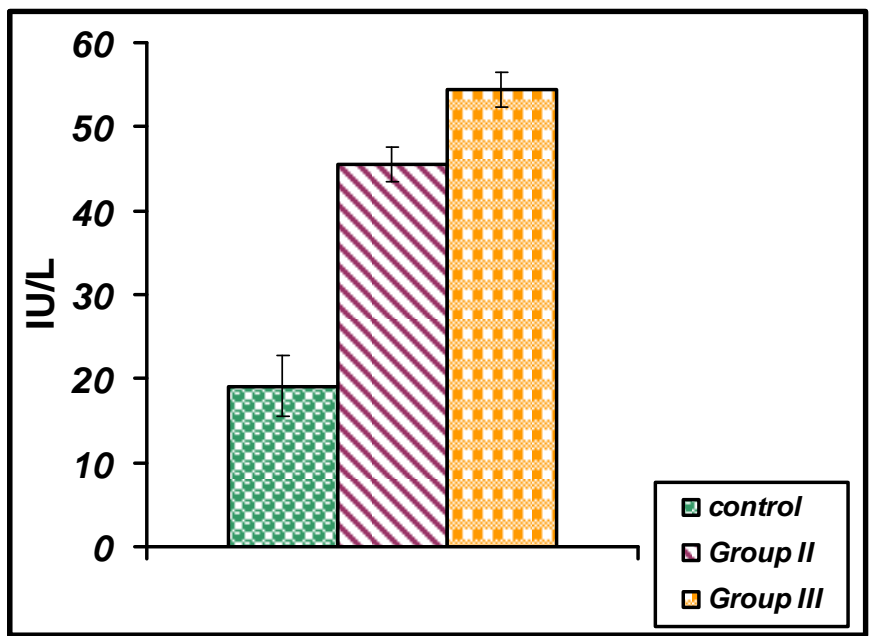

Fig (2): Mean \pm SD of AST level (IU/L) in the three studied groups 


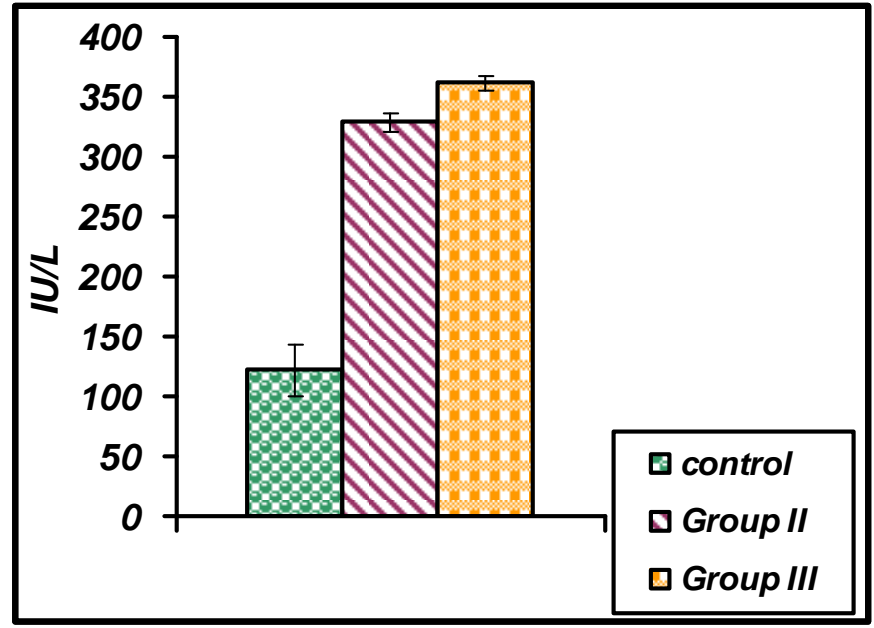

Fig (3): Mean $\pm S D$ of ALP level (IU/L) in the three studied groups

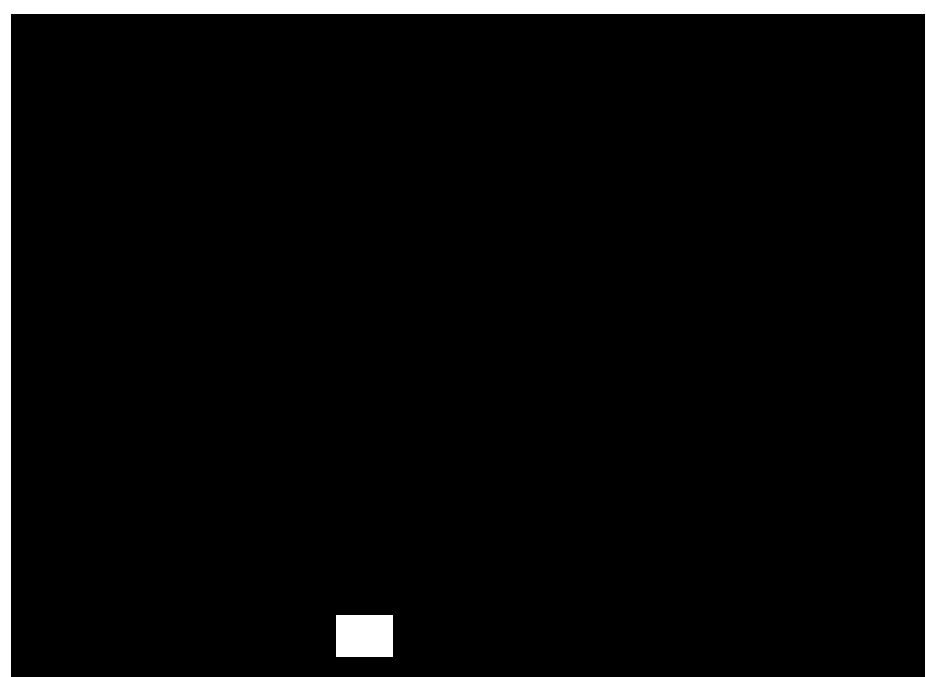

Fig (4): Mean \pm SD of GGT level (IU/L) in the three studied groups 


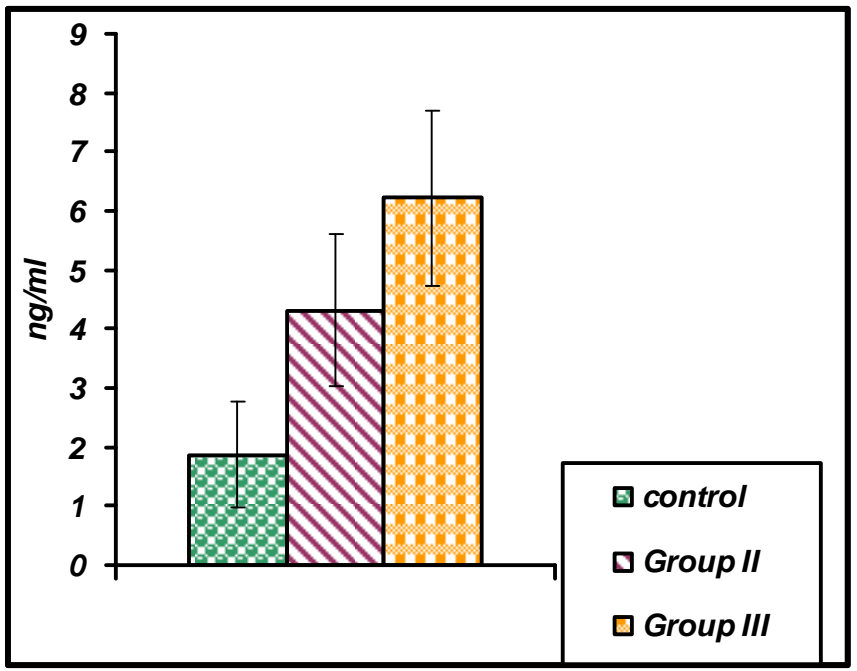

Fig (5): Mean \pm SD of IL-10 level $(\mathrm{ng} / \mathrm{ml})$ in the three studied groups

Table (2): Correlation between IL-10 and different laboratory findings in group II and group III.

\begin{tabular}{|c|c|c|c|c|c|c|}
\hline \multirow{2}{*}{} & \multicolumn{2}{|c|}{$\begin{array}{c}\text { Group I } \\
\text { (N=15) }\end{array}$} & \multicolumn{2}{c|}{$\begin{array}{c}\text { Group II } \\
\text { (N=15) }\end{array}$} & \multicolumn{2}{c|}{$\begin{array}{c}\text { Group III } \\
(\mathbf{N}=15)\end{array}$} \\
\cline { 2 - 7 } & $\mathrm{r}$ & $\mathrm{p}$ & $\mathrm{r}$ & $\mathrm{p}$ & $\mathrm{r}$ & $\mathrm{p}$ \\
\hline ALT & -0.141 & $>0.05$ & $0.695^{* *}$ & $<0.05^{*}$ & $0.777^{* *}$ & $<0.01$ \\
(IU/L) & & $\mathrm{NS}$ & & $\mathrm{S}$ & & $\mathrm{S}$ \\
\hline AST & 0.239 & $>0.05$ & $0.588^{*}$ & $<0.05$ & $0.726^{* *}$ & $<0.005$ \\
(IU/L & & $\mathrm{NS}$ & & $\mathrm{S}$ & & $\mathrm{S}$ \\
\hline ALP & -0.235 & $>0.05$ & $0.678^{* *}$ & $<0.01$ & $0.744^{* *}$ & $<0.005$ \\
(IU/L) & & $\mathrm{NS}$ & & $\mathrm{S}$ & & $\mathrm{S}$ \\
\hline GGT & 0.303 & $>0.05$ & $0.704^{* *}$ & $<0.01$ & $0.662^{* *}$ & $<0.01$ \\
(IU/L) & & $\mathrm{NS}$ & & $\mathrm{S}$ & & $\mathrm{S}$ \\
\hline S. ALB & 0.025 & $>0.05$ & 0.099 & $>0.05$ & 0.339 & $>0.05$ \\
(gm/L) & & $\mathrm{NS}$ & & $\mathrm{NS}$ & & $\mathrm{S}$ \\
\hline T. Protein & 0.017 & $>0.05$ & -0.062 & $>0.05$ & $-0.537^{*}$ & $<0.05$ \\
(gm/L) & & $\mathrm{NS}$ & & $\mathrm{NS}$ & & $\mathrm{S}$ \\
\hline A/G & -0.044 & $>0.05$ & -0.003 & $>0.05$ & $0.721^{*}$ & $<0.005$ \\
& & $\mathrm{NS}$ & & $\mathrm{NS}$ & & $\mathrm{S}$ \\
\hline Protrombin conc. & -0.083 & $>0.05$ & 0.450 & $>0.05$ & -0.135 & $<0.05$ \\
\% & & $\mathrm{NS}$ & & $\mathrm{NS}$ & & $\mathrm{NS}$ \\
\hline INR & -0.030 & $>0.05$ & $0.561 *$ & $<0.05$ & -0.178 & $>0.05$ \\
& & $\mathrm{NS}$ & & $\mathrm{S}$ & & $\mathrm{NS}$ \\
\hline
\end{tabular}




\section{DISCUSSION}

Hepatitis C virus (HCV) has emerged as a major cause of liver disease worldwide. Once infected by hepatitis $\mathrm{C}$ virus, patients have a high chance of developing a chronic disease progression, possibly leading to cirrhosis or even hepatocellular carcinoma. Resistance or susceptibility to viral infections is critically linked to cytokine release, which can be polarized towards a type 1 (IFN $\gamma$, TNF- $\alpha$, IL-2) or type 2 (IL4, IL10, IL13) pattern in helper as well as cytotoxic T-lymphocytes ${ }^{(7)}$. Interleukin 10 is considered typical cytokine released from activated $\mathrm{T}$ helper 2 type cells ${ }^{(8)}$.

On basis of the previous data the current work was designed to evaluate the role of IL-10 as a marker of Thelper 2 activity and its importance in chronicity of hepatitis $\mathrm{C}$ virus.

The present data were in agreement with those of Brady and his Colleagues ${ }^{(5)}$, who stated that HCV subverts cellular immunity by inducing IL - 10 and inhibiting IL 12 production by monocytes, which in turn inhibits the activation of DC that drive the differentiation of Th 1 cells. Also, it was reported by Cacciarell and his colleagues, ${ }^{(9)}$ and Hongyu and his colleagues $^{(1)}$ that IL-10 levels become elevated in patients with chronic hepatitis $\mathrm{C}$.

The serum level of IL-10 was assayed in 10 normal subjects, 24 HCV carriers and 27 patients with chronic hepatitis $\mathrm{C}$. The serum level of IL-10 was much higher in the patients with chronic hepatitis $\mathrm{C}$ than in normal controls and $\mathrm{HCV}$ carriers with a positive relation to the values of $\mathrm{ALT}^{(\mathbf{1})}$.

The present findings are in line with a previous report by Kakumu and his colleagues ${ }^{(10)}$ who reported increased IL-10 levels but unaltered IL -12 production in monocular cells of patients with chronic hepatitis $\mathrm{C}$.

In addition, Abayli and his colleagues. ${ }^{(11)}$ concluded that serum levels of IL-4, IL-10 but not IFN- $\gamma$ were found to be significantly increased in chronic HCV patients compared to those of control subjects. That finding may suggest the involvement of $\mathrm{TH} 2$ cytokines in the pathogenesis of chromic hepatitis $\mathrm{C}$ virus liver disease.

Also, the numbers of IL-10 producing monocytes were at least twofold higher in patients with chronic hepatitis $\mathrm{C}$ than in aviremic anti HCV seropositives and the controls thus in chronic hepatitis $\mathrm{C}$ antigen- specific cytokine induction in monocytes is apparently shifted towards predominant IL-10 induction $^{(3)}$.

Another study measured the levels of cytokines in the culture supernatant of PBMCs compared with the cytokine level of normal control, the levels of IFN- $\gamma$, TNF $-\alpha$ and IL10 of HCV patients notably increased while IL-2, IL-4, and IL-12 were not detected in the culture supernatant of PBMCs from both normal control and HCV patients after culture for 72 hours $^{(12)}$

Another study that is supported by the present results had revealed that the levels of IL-18, IL-10, TNF alpha and sIL-2 in the patients of chronic hepatitis $\mathrm{C}$ were higher than those in the healthy controls and in 
asymptomatic HCV carriers. IL-18, IL-10, TNF- $\alpha$ and SIL-2 coparticipate in the pathogenesis of chronic hepatitis $\mathrm{C}$, and are used to evaluate the effect of IFN on the immune state of organisms, and IL 10 and sIL-2 are important for predicting the anti-viral efficacy of IFN $^{(13)}$

Controversial to the present results, the results of Hassoba and his colleagues. ${ }^{(14)}$ that was performed on 66 Egyptian patients of chronic Hepatitis - $\mathrm{C}$ related illness and showed that spontaneous IL-10 was undetectable in patients with HCC or controls. Only 5/22 (23\%) of their patients with cirrhosis showed detectable levels of IL-10.

Another study done by Takegoshi and his colleagues. ${ }^{(15)}$ in which IFNgamma IL-12 P70, Il 12 p40 and IL10 as well as NK cell activity were assayed in six patients with normal ALT, $22 \mathrm{HCV}$-infected individuals with chronic hepatitis $(\mathrm{CH}), 13$ cases of liver cirrhosis (LC) and 26 agematched controls, no inter-group differences were observed for IL12 p70, Il 12 p40 and Il-10 production and NK cell activity.

Further studies are recommended to be done to fulfill the sources and mechanisms of increased IL-10 level in chronic hepatitis patients and the possibility to use IL-10 as a therapy to treat the active disease, also the use of IL-10 as a preliminary testing in patients with chronic hepatitis $\mathrm{C}$ is recommended and recommendation agrees with previous studies.

\section{REFERENCES}

1. Hongyu, J.A.; Hie, D.U. and Huafeng, CAI. (2003): Clinical observation of serum IL-18 and sIl-2R levels in patients with chronic hepatitis $\mathrm{C}$ pre-and post antiviral treatment. Chin. Med. J, 116(4): 605-608.

2. Antonaci, S.; Piazzollo, G.; Napoli, N. and Schiraldi, $O$. (2001): Relationship between $T$ lymphocyte responsivness and $\mathrm{T}$ helper1/T-helper 2 type cytokine release in chronic hepatitis (critical reappraisal). Microbios., 106(415): 203-12.

3. Woitas, RP.; Petersen, U.; Moshage, D.; Brackmann, H.H. and Spengler, U. (2002): HCVspecific cytokine induction in monocytes of patients with different outcomes of hepatitis C. World J. Gastroenterol., 8(3):562566.

4. Kanapp, S.; Hennig, BJW. and Thursz, MR. (2003): Interleukin10 promoter polymorphisms and the outcome of hepatitis $\mathrm{C}$ virus infection. Immunogenetics., 55:362-369.

5. Brady, M.T.; MacDonald, A.J.; and Mills, K.H. (2003): Hepatitis $\mathrm{C}$ virus non-structural protein 4 suppression Th1 responses by stimulating IL-10 production from monocytes. Eur. J. Immunol., 33(12): 3448-57.

6. KirKowood, B. R. (1989): Essentials of Medical Statistics. Blackwell Scientific Publication. Oxford London, pp. 151.

7. Groux, H. (2003): Type 1 Tregulatory cells and their role in 
the control of immune responses.

Transplantation 75:85-89.

8. Luik, A.; Knapp, S.; Thursz, M.; Thomas, H.C. and Schlaak JF (2004): Autoregulatory role of interleukin-10 in hepatitis $\mathrm{C}$ patients treated with IFN-alpha. J. Interferon Cytokine Res., 24(10):585-593.

9. Cacciarelli, T.V.; Martinez, O.M.; Gish, R.G. and Krams, S.M. (1996): Immunoregulatory cytokines in chronic hepatitis $\mathrm{C}$ virus infection: pre- and post treatment with IFN-alpha. Hepatology 24 (1):6-9.

10. Kakumu, S.; Okumura, A.; Ishikawa, T.; Iwata, K.; Yano, M. and Yoshioka, K. (1997): Production of interleukins 10 and 12 by peripheral blood mononuclear cells(PBMC)in chronic hepatitis $\mathrm{C}$ virus infection Clin. Exp. Immunol., 108:138143.

11. Abayli, B.; Canataroglu, A. and Akkiz, H. (2003): Serum profile of $\mathrm{T}$ helper 1 and $\mathrm{T}$ helper 2 cytokines in patients with chronic hepatitis $\mathrm{C}$ virus infection. Turk. J. Gastroenterol, 230(1):7-11.
12. Dong, Y.; Zhang, H.F.; Chen, H. and Cheng, Y. (2004): The cytokine secretion of peripheral blood mononucleocytes from patients infected with $\mathrm{HCV}$. (Article in Chinese) $\mathrm{Xi}$ Bao $\mathrm{Yu}$ Fen Zi Mian Yi Xue Za Zhi.; 20(3):331-337.

13. Jia, H.Y.; Du, J.; Zhu, S.H. and Cai, H.F. (2002): The roles of serum IL-18, IL-10, TNF-alpha and sIL-2R in patients with chronic hepatitis C. Hepatobiliary pancreat. Dis. Int.1 (3):378-382.

14. Hassoba, H.; Leheta, O.; Sayed, A. and Serwah, A. (2004): IL-10 and IL-12p40 in Egyptian patients with HCV-related chronic liver disease. Egyp. J. Immunol., 10(1):1-8.

15. Takegoshi, K.; Ogai, H. and Ohmoto, Y. (2004): Production of IFN-gamma and IL-12 by peripheral whole blood is maintained in hepatitis $\mathrm{C}$ virus patients with persistently normal alanine transferase activity; A preliminary report. Hepatol. Res., (2):81-88. 
دور الإنترلوكين - - 1 كدلالة لنشاط الخلايا الليمفاوية المساعدة عند

المرضى المصريين المصابين بالالتهاب الكبدي الفيروسي سي

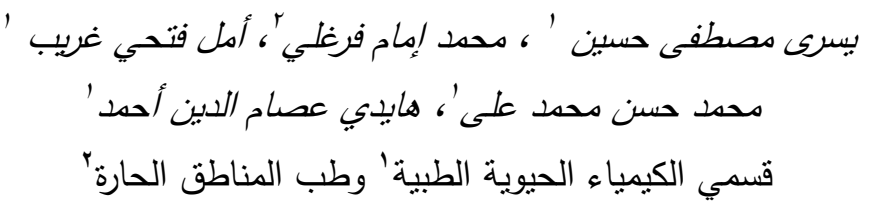

كلية الطب - جامعة الزقازيق

اجريت هذه الدراسـة في قسمي الكيميـاء الحيويـة الطبيـة وطب المنـاطق الحارة في مستشفيات جامعـة

وقد شملت هذه الدراسة 0؛ حالة قسمت كالتالى:المجموعة الأولى: 0 امتطوعا من الأصحاء كمجموعة ضـابطة. المجموعة الثانية : 10 فرداً مصحوبين بقياس إنزيمي مناعى موجب و تفاعل تسلسلي عديد البلمرة سلبي للفيروس .المجموعة الثالثة: 10 مريضا مزمنا مصحوبين بقياس إنزيمي مناعى موجب و تفاعل تسلسلي عديد البلمرة موجب للفيروس. وتم قياس: مسنوى الإنترلوكين- •. في الدم ووظائف الكبد (نشاط انزيم الفوسفاتيز القلوي، الانزيم الناقل

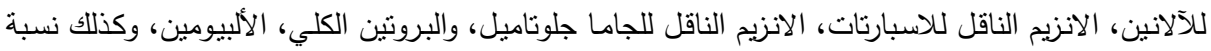
الألبيومين إلى الجلوبيولين). الأجسام المضادة للفيروس سي، والحمض النووي الريبوسي للفيروس سي. لإنيات وجد في

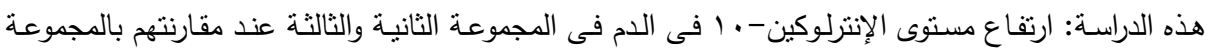

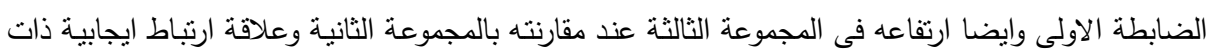
دلالة احصائية بين مسنوى الإنترلوكين- · 1 فى الدم وكل من نشاط الانزيم الناقل للالانين ونشاط الانزيم الناقل للاسبارتات والانزيم الناقل للجاما جلوتاميل ونشاط الانزيم الفوسفاتيز القلوى. وارتفاع نشاط الانتين لناطيم الناقل للالانين فى المجموعة الثانية والثالثة عند مقارنته بالمجموعة الضابطة الاولى وايضا ارتفاعه فى المجموعة الثالثة عند مقارنته بالمجموعة الثانية . . وارتفاع نشاط الانزيم الناقل للاسبارتات فى المجموعة الثانية والثالثة عند مقارنته بالمجموعة الضابطة الاولى وايضا ارتفاعه فى المجموعة الثالثة عند مقارنته بالمجموعة الثانية .و ارتفاع نشاط

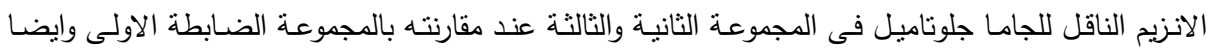

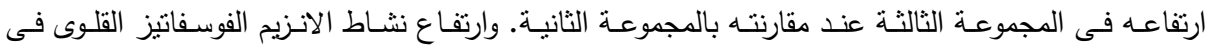

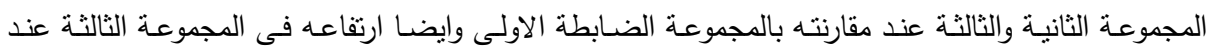


وانخفاض ذو دلالة إحصائية في كلا من الألبومين والبروتين الكلي في المجموعة الثانية عند مقارنتها

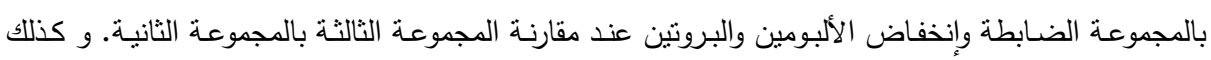

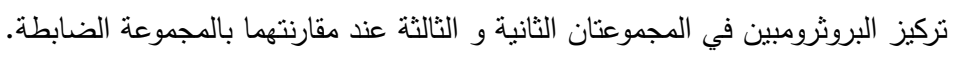

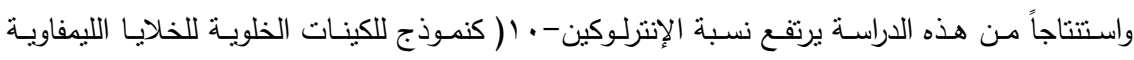

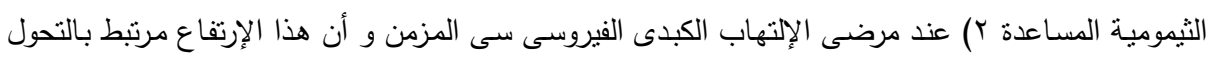

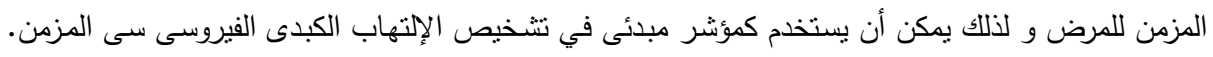

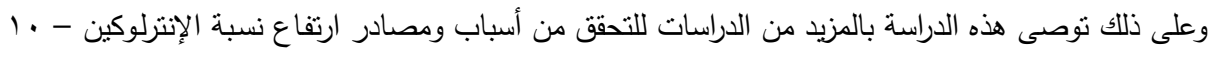

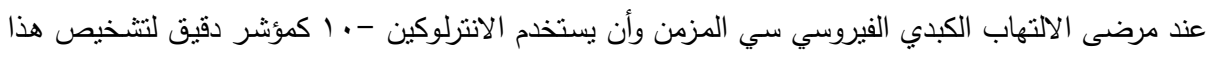
المرض. وذللك يتوافق مع دراسات كثيرة سابقة. 